Journal for Maritime Research:

Dr. Howard Fuller, University of Wolverhampton

\title{
Ronald S. Coddington, Faces of the Civil War Navies: An Album of Union and Confederate Sailors
}

Baltimore, 2016, pp. 401, hb, \$32.95, ISBN: 9781421421360

This is the latest work by the author in his series of biographical sketches, [Union] Faces of the Civil War (2004), Faces of the Confederacy (2008) and African American Faces of the Civil War (2012), turned out like clockwork every four years by Johns Hopkins University Press. There are 77 'profiles', each one including a photograph—mostly from cartes de visite taken during the period (1861-1865) — and fully-referenced details of the historical figure in question. You will not find startling new details about flag officers or other well-known ('top-down') Civil War heroes as such. This volume is more about supplementing our understanding of this greatest of nineteenth-century conflicts at sea with not just a bottom-up, 'face of battle' perspective but with collateral details often left out of analytical narratives preoccupied with the big pictures and interpretations and rather unfortunately obliged to leave the everyday, human 'face' of our collective past in the shadows. 'The history of the Civil War', the author notes, is 'the stories of its soldiers and sailors' [xviii].

Leaving the excellent Foreword by renowned American naval historian Craig L. Symonds aside for the moment, Coddington's Preface is a fascinating look at a very busy facet of historical research taking place in specialist magazines and online. In this instance, auction sites like eBay have seen cartes de visite publicly available for acquisition and dissemination like never before. This parallels in a striking manner the advent of photography itself in the late 1820s, with Louis Jacques Mandé Daguerre's and Joseph Nicéphore Niépce's processes 
combined to produce an art-form and technology truly world-changing. By the outbreak of the Civil War in 1861, the daguerreotype was supplanted by the radically more affordable, mass-consumable tintype. Now everyday people-in peace and war-could imprint themselves quite literally into the historical record. 'They were the Photography Generation' observes Faces of the Civil War Navies. 'Essentially a democratic medium, photography individualized the identity of the common soldier and sailor' [xviii]. And so today equally momentous advances like the global internet allow independent collectors and researchers like Coddington to bring these lives to light.

Take for instance Acting Assistant Paymaster George Work, lost in the USS Tecumseh at the Battle of Mobile Bay (5 August, 1864) when the ironclad-monitor struck a Confederate 'torpedo' or mine and sank in less than a minute. His photo is of a serious-looking bachelor in his early forties who put aside his career as a schoolteacher in the 1850 s to amass a 'small fortune' as a trader - and setting that aside to join the U.S. Navy in 1864. Canadian-born Ebenezer McKay also put aside a lucrative practice (establishing his own fishery in Michigan) and also fought for the Union aboard a monitor, the USS Weehawken. Before his one-year term of enlistment as an Ordinary Seaman expired his vessel took a close-range pummelling from Charleston's forts (7 April, 1863) but then captured the Confederate ironclad-ram Atlanta later in June. McKay passed away in 1920 at the ripe old age of eightysix. $\quad 1^{\text {st }}$ Lieutenant John Grimball of the Confederate States Navy, by contrast, lived to eighty-two (1922) and had served on board the iron-armoured ram CSS Arkansas when it blasted its way through the combined Union squadrons before Vicksburg (15 July, 1862). In 1864 he was transferred overseas; to the British-built commerce raider CSS Shenandoah, later notorious for decimating the Yankee Pacific whaling fleet well after Lee had surrendered to Grant at Appomattox. Fearing that vengeful U.S. authorities might convict the 
officers and crew of piracy, the Shenandoah quietly sailed 10,000 miles back across the world to Liverpool, presenting as Grimball recalled the ghostly spectacle of a warship of a nation which no longer existed. He was 25.

Unique experiences like these were all the more extraordinary, as Symonds points out, when $80 \%$ of the enlisted men in Civil War navies were 'entirely new to the service' and all were volunteers; there was no draft for sailors. And yet half were foreign-born (some $20 \%$ alone were Irish), with another fifth of the U.S. Navy comprised of African Americans. Surveying the profile photos, Symonds reflects that some of the subjects struck a defiant expression, others seemed more resigned and 'not one of them is smiling'. How very mid-Victorian.

The author doesn't suggest what volume might appear next, if any. As such, the novelty might be short-lived; this type of series probably won't feature on university reading lists, for example. The lack of a list of the profiles/their names in the table of contents, perhaps grouped 'North' or 'South', or demarcating officers and men, is something which might confuse or frustrate readers increasingly prone to finding raw information as quickly as possible. Coddington only offers profile titles as they appear page after page, almost at random, such as 'Such Men Soon Find Death' (the first profile), 'Face to Face with a Rebel', '\$2,545.43', and 'A Strict Accounting of Stripped Ships'. The last profile is titled 'He Helped Preserve the Memory of the Naval War', with a carte de visite of 16 year-old Richard Rush, a U.S. Naval Academy cadet during the war, yet who picked up later in life the burden of overseeing the production of the first four volumes of the Official Records of the Union and Confederate Navies. These types of details - these memories - are therefore best appreciated almost as a literary digestif. Faces of the Civil War Navies is a strongly encouraged addition to anyone's naval/maritime library because it is deeply entertaining and 
informative; and really, what else should a history be but an intellectual surge of wisdom and insight which resonates emotionally? 